\title{
Effect of Aqueous Extract of Sphenostylis stenocarpa on Some Liver and Kidney Parameters of Wistar Rat
}

\author{
Okoye Ngozi Franca $^{1 *}$ and Esiobise Ufuoma Monica ${ }^{1}$ \\ ${ }^{1}$ Department of Biochemistry, University of Port Harcourt, Choba, Nigeria.
}

\begin{abstract}
Authors' contributions
This work was carried out in collaboration between both authors. Author ONF designed the study, supervised the work, managed the analyses of the study and wrote the protocol and the first draft of the manuscript. Author EUM performed the experiment and managed the literature searches. Both authors read and approved the final manuscript.
\end{abstract}

Article Information

DOI: $10.9734 /$ IJBCRR/2017/34274 Editor(s): (1) Mohamed Fawzy Ramadan Hassanien, Biochemistry Department, Zagazig University, Egypt.
Reviewers:

(1) Morebise, Olugbenga, All Saints University School of Medicine, West Indies. (2) Wagih Mommtaz Ghannam, Mansoura University, Egypt. Complete Peer review History: http://www.sciencedomain.org/review-history/19940

Original Research Article

Received 22 $2^{\text {nd }}$ May 2017

Accepted $21^{\text {st }}$ June 2017

Published $8^{\text {th }}$ July 2017

\begin{abstract}
Aim: Aqueous extract of the seed of African Yam Bean (Sphenostylis stenocarpa) is used in Nigerian alternative medicine for the treatment of hypertension. The objective of this study is to investigate the effect of Sphenostylis stenocarpa seed extract on the liver and kidney functions of wistar rats. The biochemical parameters assayed were alkaline phosphatase (ALP), lactate dehydrogenase (LDH), urea and creatinine.

Materials and Methods: Varying doses of the aqueous extract of the Sphenostylis stenocarpa, were administered to the rats for a period of ten days and the biochemical parameters; ALP, LDH, urea and creatinine levels were determined using spectrophotometric methods.

Results: There was significant decrease $p=0.05$ in the urea concentration in the serum. The highest decrease of $0.70 \pm 0.08 \mathrm{vs}$ control $0.97 \pm 0.00 \mathrm{mmol} / \mathrm{l}$ was obtained after the 10 days duration at the highest dose $(3 \mathrm{ml} / 100 \mathrm{~g}$ body weight). Additionally, the creatinine concentration in the serum of the experimental animals also showed a significant decrease. The highest decrease of $81 \pm 1.63 \mathrm{vs}$ control $110 \pm 0.00 \mu \mathrm{mol} / \mathrm{l}$ was obtained after the 10 days period at the highest dose $(3 \mathrm{ml} / 100 \mathrm{~g}$ body weight). The study also showed that the aqueous extract of Sphenostylis stenocarpa had no significant effect on the ALP and LDH activities of the experimental rats.
\end{abstract}


Conclusion: The decrease on the urea and creatinine levels may be contributing to the reduction in high blood pressure in the individuals taking this tea extract. Furthermore, the study showed that the aqueous extract had no harmful effects on the liver profile of the rats.

Keywords: Alkaline phosphatase; creatinine; lactate dehydrogenase; Sphenostylis stenocarpa; triglycerides; urea.

\section{INTRODUCTION}

African yam bean (AYB) Sphenostylis stenocarpa, known locally in Igbo as uzaaku, is a climbing legume adapted to lowland tropical conditions. It is one of the lesser-known legumes $[1,2]$ and widely cultivated in the southern parts of Nigeria. The water drained after boiling the seeds of Sphenostylis stenocarpa have been used to reduce high blood pressure levels in patients practising alternative medicine. However, there is no documented evidence to support this claim. Hence the motive of this research. The potential role of AYB in the management of many aging and chronic non communicable diseases has been reported [3]. In Ghana, the water drained after boiling may be drunk by lactating mothers to increase their milk production [4]. The economic potential of AYB has been recognized, especially in reducing malnutrition among Africans [5]. These health benefits can be marred by the presence of antinutrients. Some processing methods however, such as soaking, boiling, fermentation, roasting, among others are known to achieve reduction or elimination of the anti-nutritional factors which affect the nutrients $[5,6,7,8,9,10,11]$.The legumes are a good source of dietary protein [12]. They are cheaper than animal products such as meat, fish, poultry and egg, therefore they are consumed worldwide as a major source of cheap protein and especially in the developing or poor countries where consumption of animal protein may be limited as a result of economic, social, cultural or religious factors [13]. Global food security however is becoming shaky with increasing dependence on a few major staple crops. This has resulted in an alarming reduction not only in crop diversity but also in the variability within crops. This therefore emphasizes the need for the collection and conservation of diversity within species. Usually when this done, there is the possibility for stockpiling crops of converse characteristics - for example, stockpiling low yielding varieties with high yielding ones.

AYB is cultivated both for the seeds and tubers, because of its valuable and prominent source of plant protein (amino acids -lysine and methionine) in the diets of consumers [14]. The tuber which is found beneath the ground has resemblance with sweet potatoes or Irish potatoes. Above ground it produces good yields of edible seeds. It could be found in forests, open wooded grasslands, rocky fields, and marshy grounds as weed and cultivated crops [15]. It grows on a wide range of soils including acid and highly leached sandy soils at altitudes from sea level to $1950 \mathrm{~m} \mathrm{[16].} \mathrm{In} \mathrm{the} \mathrm{area} \mathrm{of} \mathrm{cultivation,} \mathrm{it}$ serves as security crop prior to the new season harvest of main staples such as maize, sorghum, yam and cassava in the tropics. Different studies on nutritional, chemical composition, and extraction condition for optimum solubilization of the pulse protein have been studied $[17,18,19]$. African yam beans ( $S$. stenocarpa) however has anti-nutritional factors such as phytin and lectin.

It is of great importance to know the nutrient, toxic substance as well as the anti-physiological substance composition and organoleptic properties of locally available foods in any community or country. Knowledge and use of local foods can help eliminate malnutrition. One of the problems of planning therapeutic diets with local foods is limited information on their nutrient composition [20]. It has been proposed that the fight against malnutrition in developing countries should be on the use of mixtures of tubers, cereals and legumes indigenous to them [21]. Urbanization has made people forget their traditional foods and favour convenient foods which are mostly nutritionally inadequate and expensive. The most dietary deficit is protein of high biological value and this was attributed to the high cost of animal protein [20]. Vegetable proteins however complement each other if wellchosen and will have a nutritive value as good as animal protein $[2,13,21]$.

For quite some time, legumes were considered not too important; but now, their food use is increasing with recent discoveries concerning their many nutritional and health properties [20]. It has been documented that legumes contain 2-3 times the protein of cereal grains and no other plant food is as rich in protein as legumes in their natural state $[2,20,21]$. Water soluble non 
starch polysaccharides (NSP) that have viscous properties occur mostly in legumes and its benefit in the prevention/management of diabetes and cardiovascular diseases have been reported [22]. One such legume of interests is African yam bean (Sphenostylis stenocarpa) (AYB).

African yam bean (AYB) is highly nutritious with high protein, mineral and fiber content. Its protein content is reported to be like that of some major and commonly consumed legumes. Its amino acid profile is comparable if not better than those of cowpea, soy bean and pigeon pea $[1,17,23]$. It has high metabolic energy, low true protein digestibility $(62.9 \%)$, moderate mineral content, the amino and fatty acids contents are comparable to those of most edible pulses $[17,24,25]$. It has a higher water absorption capacity when compared to cowpea [20]. The alkaline phosphatases are a group of enzymes that hydrolyze organic phosphates at high $\mathrm{pH}$. They are present in most tissues, but are in particularly high concentrations in the osteoblasts of bones and the cells of the hepatobilary tract, intestinal wall, renal tubules and placenta. The primary importance of measuring alkaline phosphatase is to check the possibility of bone disease or liver disease. Thus, the serum alkaline phosphatase is a measure of the hepatobiliary system and the flow of bile into the small intestine [26]. The main function of LDH is the conversion of pyruvic acid, the final product of glycolysis, to lactic acid and vice versa in muscle through production of cellular energy [26]. It is an enzyme that helps facilitate the process of turning sugar into energy for cells to use. However, it is normally present in small amounts in most active organs. Thus, high level of this enzyme may indicate unusual conditions that can result from liver disease, muscular disorder (e.g. acute myocardial infarction) and even cancer disease [26].Urea is synthesized in the body of many organisms as part of the urea cycle, either from the oxidation of amino acids or from ammonia. Amino acids from ingested food that are not used for the synthesis of proteins and other biological substances are oxidized by the body, yielding urea and carbon dioxide, as an alternative source of energy [27]. The oxidation pathway starts with the removal of the amino group by a transaminase; the amino group is then fed into the urea cycle. Creatinine is a protein breakdown product and its level is a reflection of the bodies muscle mass. Creatinine is a metabolite of creatine. Production is endogenous, determined by muscle mass, unlike urea is almost independent of diet. It increases in renal failure $[26,28,29]$.

The water drained from boiled African yam bean have been used to reduce high blood pressure levels when consumed. There are no documented evidence to support this claim. So the aim of this study, is to investigate the effects of this aqueous extract of Sphenostylis stenocarpa on the liver enzymes and also on the urea and creatinine levels using wistar rat as the experimental animal.

\section{MATERIALS AND METHODS}

\subsection{Collection and Identification of Plant Material}

Reagent kits were bought from Randox Laboratories Ltd. Ardmore, Diamond Road, Crumlin, Co. Antrim, United Kingdom BT29 4QY.

The African yam bean (Sphenostylis stenocarpa) seed used for this study was obtained from Enugu State, Nigeria. It was identified at the Federal Ministry of Agriculture, Enugu State, Nigeria. The African yam bean was prepared by boiling 10 grams in $200 \mathrm{ml}$ of water for an hour. The method of administration was forced feeding and this was done twice daily.

\subsection{Experimental Animals}

A total of 36 wistar rats were used for the purpose of this research. The rats were arranged in 4 groups and these groups had 3 subgroups containing 3 rats each. The groups were labelled according to the dose of extract (of the boiled AYB) administered orally to the rats daily.

Group 1 (Control), this group was further divided into 3 subgroups. The animals here had access to enough feed and water daily but were not given any of the plant material.

Group $2(1 \mathrm{ml})$, this group was further divided into 3 subgroups and $1 \mathrm{ml}$ of the plant solution was administered at days 3,7 and 10 days respectively.

Group $3(2 \mathrm{ml})$, this group was further divided into 3 subgroups and $2 \mathrm{ml}$ of the plant solution was administered at days 3,7 and 10 days respectively.

Group $4(3 \mathrm{ml})$ this group was further divided into 3 subgroups and $3 \mathrm{ml}$ of the plant solution 
was administered at days 3, 7 and 10 days respectively.

\subsection{Collection of Blood Samples}

After 3 days, the first set of rats were sacrificed taking 3 rats from each of the major groups (control, $1 \mathrm{ml}, 2 \mathrm{ml}$ and $3 \mathrm{ml}$ ). The same procedure was carried out after 7 days and 10 days. Chloroform was used to anaesthetize the rats which were placed in a desiccator (an air tight) container and blood sample collected.

\subsection{Alkaline Phospatase Determination}

Reagent kit contained 1: Buffer Diethanolamine buffer (1 mol/l,pH 9.8), $\mathrm{MgCl}_{2} \quad 0.5 \mathrm{mmol} / \mathrm{l}$. 2: Substrate p-nitrophenylphosphate $(10 \mathrm{mmol})$.

ALP levels were determined by colorimetric method. $0.05 \mathrm{ml}$ of sample was mixed with $3.00 \mathrm{ml}$ of reagent in a $1 \mathrm{~cm}$ light path cuvette. The absorbance of the mixture was read against air at $37^{\circ} \mathrm{C}$ at $405 \mathrm{~nm}$ using spectronic - 20 spectrophotometer. A timer was started simultaneously and the absorbance of the mixture was read again after 1,2 and 3 minutes.

\section{Calculation:}

The ALP activity was calculated using the following formulae

$$
\mathrm{IU} / \mathrm{L}=3300 \times \Delta \mathrm{A} 405 \mathrm{~nm} / \mathrm{min}
$$

\subsection{Lactate Dehydrogenase Analysis}

Reagent kit contained: R1a: Buffer/substrate: Phosphate buffer (50 mmol/l, pH 9.8), Pyruvate (0.6 mmol/l), R1b: NADH (0.18 mmol/l).

$\mathrm{LDH}$ levels were determined by UV kinetic method. $0.05 \mathrm{ml}$ of sample was mixed with $3.00 \mathrm{ml}$ of reagent in a $1 \mathrm{~cm}$ light path cuvette. The absorbance of the mixture was read against air at $37^{\circ} \mathrm{C}$ at $340 \mathrm{~nm}$ using spectronic - 20 spectrophotometer. A timer was started simultaneously and the absorbance of the mixture was read again after 1,2 and 3 minutes.

\subsection{Estimation of Urea Using Diacetylmonoxime Method [30]}

\section{Principle of Method:}

Urea in the presence of strong acid and a reducing agent reacts with Diacetylmonoxime to give a pink coloured compound, which was measured at $520 \mathrm{~nm}$. A serum sample free of haemolysis was used.

\section{Reagent and standards:}

(A) Acid Solution; Conc. Sulphuric acid, Conc. Ortho phosphoric acid and Ferric chloride.

(B) Colour Solution; Diacetylmonoxime, Sodium chloride, and 4-aminoantipyrine.

(C) Standard; A $60 \mathrm{mmol} / \mathrm{l}$ standard serially diluted to $3,6,15,30$ and $45 \mathrm{mmol} / \mathrm{l}$.

Procedure 1: For Blood urea.

$\begin{array}{lllll} & \text { STD } & \text { TEST } & \text { QC } & \text { BLANK } \\ \text { Reagent A } & 2.5 \mathrm{ml} & 2.5 \mathrm{ml} & 2.5 \mathrm{ml} & 2.5 \mathrm{ml} \\ \text { Reagent B } & 2.5 \mathrm{ml} & 2.5 \mathrm{ml} & 2.5 \mathrm{ml} & 2.5 \mathrm{ml} \\ \text { Standards } & 50 \mathrm{u} / \mathrm{l} & \ldots \ldots . & \ldots \ldots \ldots & \ldots \ldots \ldots \\ \text { Sample } & \ldots \ldots \ldots & 50 \mathrm{u} / \mathrm{l} & \ldots \ldots \ldots & \ldots \ldots \ldots \ldots \\ \text { QC } & \ldots \ldots \ldots & \ldots \ldots \ldots & 50 \mathrm{u} / \mathrm{l} & \ldots \ldots \ldots \ldots\end{array}$

Absorbance was read at $520 \mathrm{~nm}$ with Spectronic -20 spectrophotometer.

\section{Calculations:}

Concentration of Sample $=\underline{\Delta \mathrm{A}_{\text {sample }}} \quad \mathrm{X} \quad \mathrm{C}_{\text {standard }}=\mathrm{mg} / \mathrm{dL}$ urea $\times 0.1665=\mathrm{mmol} / \mathrm{l}$

$$
\Delta \mathrm{A}_{\text {standard }}
$$

Reference Range for Blood urea nitrogen: $2.5-6.6 \mathrm{mmol} / \mathrm{l}$. 


\subsection{Creatinine Determination}

Creatinine levels were determined by colorimetric method (with deproteinization)

The principle of this method is that creatinine in alkaline solution reacts with picrate to form a coloured complex [31,32,33].

The Reagent kit contained solution 1: Standard (177 umol/l), solution 2: Picric acid (35 mmol/l), solution 3: Sodium hydroxide (1.6 mol/l), TA 651 Trichloroacetic acid (TCA) (1.2 mol/l). The Working reagent was prepared by mixing $10 \mathrm{ml}$ of solution 2 and $10 \mathrm{ml}$ of solution 3 .

The sample was first deproteinized by mixing 1.0 $\mathrm{ml}$ of Trichloroacetic acid (TCA) and $1.0 \mathrm{ml}$ of sample. The mixture was vigorously stirred with a glass rod to evenly disperse the precipitate. The mixture was then centrifuged at $2500 \mathrm{rpm}$ for 10 minutes, the supernatant was then separated and used for the assay as listed below:

$1.00 \mathrm{ml}$ of the working reagent was mixed with $1.00 \mathrm{ml}$ of the supernatant. The standard tube contained $1.00 \mathrm{ml}$ of the working reagent, $0.5 \mathrm{ml}$ of TCA and $0.5 \mathrm{ml}$ of solution 1 . The blank tube had $1.00 \mathrm{ml}$ of working reagent, $0.5 \mathrm{ml}$ of TCA and $0.5 \mathrm{ml}$ of distilled water. The mixture was let to stand for 20 minutes at $25^{\circ} \mathrm{C}$ and the absorbance of the sample and standard were read against the blank at $520 \mathrm{~nm}$ with Spectronic -20 spectrophotometer.

\section{Calculations:}

$$
\underline{\Delta \mathrm{A}_{\text {sample }}} \quad \mathrm{x} \quad 177=\mathrm{umol} / \mathrm{l}
$$

Normal values: $44-80$ umol/l

\subsection{Statistical Analysis}

All data are expressed as mean \pm standard deviation. Statistical analysis was performed using Graph Pad Prism version 7.0. The data was analyzed using one-way analysis of variance (ANOVA) followed by post Hoc Turkey's multiple comparison tests, $\mathrm{p}=0.05$ were considered as significant.

\section{RESULTS}

Tables 1 to 4 show the results obtained in this study There was significant decrease $p=0.05$ in the urea concentration in the serum. The highest decrease of $0.70 \pm 0.08$ vs control $0.97 \pm 0.00$ $\mathrm{mmol} / \mathrm{l}$ was obtained after the 10 days duration at the highest dose (3 $\mathrm{ml} / 100 \mathrm{~g}$ body weight). Additionally, the creatinine concentration in the serum of the experimental animals also showed a significant decrease. The study also showed that the aqueous extract of Sphenostylis stenocarpa had no significant effect on the ALP and LDH activities of the experimental rats.

\section{DISCUSSION}

There have been a lot of research work carried out on the medicinal aspects of Sphenostylis stenocarpa. However, not much have been done on the area of using the aqueous extract of the seed to reduce the levels of high blood pressure in humans. Although there have been claims from individuals practising alternative medicine on the potential benefits of the aqueous extracts of this plant, there is no documented scientific evidence to support this very claim. It is hoped that the present research work will be of help in this case. There are immense nutritional potentials and possibilities in neglected and underutilized crop species. African yam bean (Sphenostylis stenocarpa), a tropical legume is one of such species with duo-food products [8]. Apart from the nutritional potentials of this crop, there lies a lot of other health benefits that can be derived from this plant. The result of the serum alkaline phosphatase and lactate dehydrogenase levels followed a similar pattern. There was a non-significant $(p=0.05)$ increase in the levels of these parameters in the test groups compared to their levels in the Control. The discrepancies in significance levels can however be attributed to the differences in experiment duration and differences in the quantity/concentration of the extract fed to the experimental animals. The increase in serum alkaline phosphatase level could be attributed to necrosis of some organs. Necrosis is because of intrahepatic cholestasis in which bile secretion from the hepatocytes into the canaliculi is impaired due to toxins. When this happens, there is an increased synthesis of alkaline phosphatase in the affected duct and this increases the level of the enzyme in the plasma [34]. African yam bean has been shown to have some anti-nutritional factors which may be responsible for these observations. These antinutritional factors can be reduced by using efficient processing techniques and proper cooking [35]. Good processing ensures safe consumption of African yam bean meals by 
human and livestock. The result obtained by Anosike et al., [36] showed a decrease in alkaline phosphatase activity of wistar rats fed with soybean supplemented diet. Alkaline phosphatase is found mainly in the bile ducts of the liver. There can be high levels of the ALP enzyme found with some types of liver and bone disease. High levels may indicate there is a problem with bile flow.

Table 1. In vivo effect of the Administration of the Aqueous Extract of AYB Seed on ALP of wistar rats

\begin{tabular}{llll}
\hline $\begin{array}{l}\text { Sphenostylis } \\
\text { sternocarpa conc. } \\
\text { ml/100g body wt. }\end{array}$ & Day 3 (IU/L) & Day 7 (IU/L) & Day 10 (IU/L) \\
\hline Group 1 (Control) & $22.73 \pm 2.66$ & $19.20 \pm 1.50$ & $20.12 \pm 2.27$ \\
Group 2 (1 ml) & $22.34 \pm 2.01$ & $23.59 \pm 1.67$ & $24.56 \pm 2.42$ \\
Group 3 (2 ml) & $23.12 \pm 1.79$ & $24.77 \pm 2.46$ & $25.00 \pm 1.97$ \\
Group 4 (3 ml) & $24.21 \pm 2.49$ & $24.67 \pm 2.72$ & $25.40 \pm 1.25$ \\
\hline \multicolumn{4}{c}{ No significant difference was observed at $p=0.05$ for ALP at different concentrations } \\
& Values are shown as Mean \pm Standard deviation
\end{tabular}

Table 2. In vivo effect of the Administration of the Aqueous Extract of AYB Seed on LDH of wistar rats

\begin{tabular}{|c|c|c|c|}
\hline $\begin{array}{l}\text { Sphenostylis } \\
\text { sternocarpa } \\
\mathrm{ml} / 100 \mathrm{~g} \text { body wt. }\end{array}$ & $\begin{array}{l}\text { Day } 3(\mathrm{IU} / \mathrm{L}) \\
\text { conc. }\end{array}$ & Day7 (IU/L) & Day 10 (IU/L) \\
\hline Group 1 (Control) & $18.47 \pm 1.45$ & $19.18 \pm 1.18$ & $15.46 \pm 1.02$ \\
\hline Group 2 ( $1 \mathrm{ml})$ & $19.71 \pm 1.95$ & $20.44 \pm 7.25$ & $20.87 \pm 1.91$ \\
\hline Group 3 (2 ml) & $19.78 \pm 3.81$ & $19.86 \pm 4.04$ & $19.67 \pm 1.58$ \\
\hline Group 4 (3 ml) & $19.26 \pm 3.62$ & $20.58 \pm 1.94$ & $20.45 \pm 2.80$ \\
\hline
\end{tabular}

Table 3. In vivo effect of the Administration of the Aqueous Extract of AYB Seed on Urea of wistar rats

\begin{tabular}{llll}
\hline Sphenostylis sternocarpa & \multicolumn{3}{c}{ Urea $(\mathbf{m m o l} / \mathbf{l})$} \\
\cline { 2 - 4 } conc. $\mathbf{~ m l} / \mathbf{1 0 0 g}$ body wt. & Day 3 & Day 7 & Day 10 \\
\hline Group 1 (Control) & $0.97 \pm 0.00$ & $0.95 \pm 0.15$ & $0.94 \pm 0.00$ \\
Group 2 $(1 \mathrm{ml})$ & $0.87 \pm 0.18^{\mathrm{a}}$ & $0.83 \pm 0.48^{\mathrm{b}}$ & $0.81 \pm 0.18^{\mathrm{c}}$ \\
Group 3 $(2 \mathrm{ml})$ & $0.80 \pm 0.18^{\mathrm{a}}$ & $0.78 \pm 0.10^{\mathrm{b}}$ & $0.72 \pm 0.08^{\mathrm{c}}$ \\
Group 4 $(3 \mathrm{ml})$ & $0.75 \pm 0.18^{\mathrm{a}}$ & $0.71 \pm 0.10^{\mathrm{b}}$ & $0.70 \pm 0.08^{\mathrm{c}}$ \\
\hline \multicolumn{4}{c}{ Results are means of three determinations \pm standard deviation } \\
& abc Different letters in a given row denote significant difference, $p=0.05$
\end{tabular}

Table 4. In vivo effect of the Administration of the Aqueous Extract of AYB Seed on creatinine of wistar rats

\begin{tabular}{llll}
\hline Sphenostylis sternocarpa & \multicolumn{3}{c}{ Creatinine $(\boldsymbol{\mu m o l} / \mathbf{l})$} \\
\cline { 2 - 4 } conc. ml/100g body wt. & Day 3 & Day 7 & Day 10 \\
\hline Group 1 (Control) & $102 \pm 0.00$ & $103 \pm 0.01$ & $110 \pm 0.00$ \\
Group 2 (1 ml) & $98 \pm 6.83^{\mathrm{a}}$ & $95 \pm 3.12^{\mathrm{b}}$ & $90 \pm 2.95^{\mathrm{c}}$ \\
Group 3 (2 ml) & $88 \pm 4.50^{\mathrm{a}}$ & $85 \pm 1.58^{\mathrm{b}}$ & $83 \pm 1.63^{\mathrm{c}}$ \\
Group 4 (3 ml) & $87 \pm 4.50^{\mathrm{a}}$ & $84 \pm 1.58^{\mathrm{b}}$ & $81 \pm 1.63^{\mathrm{c}}$ \\
\hline \multicolumn{4}{c}{ Results are means of three determinations \pm standard deviation. } \\
& abc Different letters in a given row denote significant difference, $p=0.05$ \\
\hline
\end{tabular}




\subsection{Lactate Dehydrogenase Levels Also Showed a Non-significant Increase}

In cardiology, the measurement of lactate dehydrogenase and lactate dehydrogenase isoenzymes is a good method for the late detection (>36-48 hours after the first onset of complaints) of a myocardial infarction. The lactate dehydrogenase-1 /lactate dehydrogenase-2 ratio with a diagnostic efficiency of $93 \%-98 \%$ gives the best information. For an early diagnosis, the determination of creatine kinase MB is superior, particularly in its specificity, to the lactate dehydrogenase and lactate dehydrogenase isoenzyme determination. To monitor non-cancer disease in the liver neither lactate dehydrogenase nor its isoenzymes make a real contribution to the diagnostic process. Ample alternatives with higher sensitivity and specificity exist. Although little has been published on the use of lactate dehydrogenase and lactate dehydrogenase isoenzymes in liver malignancies, the enzyme does not emerge as the method of choice in this field of clinical enzymology at all. In hematology lactate dehydrogenase is of little diagnostic value. It makes a substantial contribution only in megaloblastic- and hemolyticanemia. However, lactate dehydrogenase-3 isoenzyme seems to be a useful marker for detecting chronic myeloid leukemia and monitoring changes of active disease into remission. Prognostic value could be attributed to lactate dehydrogenase for Hodgkin's disease and non-Hodgkin's lymphoma survival; duration and rate decrease with a higher pre-treatment lactate dehydrogenase activity $[31,32,34]$.

The study results also showed that the urea and creatinine levels when compared with the control decreased significantly in a concentration and time dependent manner throughout the experimental period. For plasma urea, the highest decrease of $0.70 \pm 0.08$ vs control $0.97 \pm$ $0.00 \mathrm{mmol} / \mathrm{l}$ was obtained after the 10 days duration at the highest dose $(3 \mathrm{ml} / 100 \mathrm{~g}$ body weight). For plasma creatinine, the highest decrease of $81 \pm 1.63$ vs control $110 \pm 0.00 \mathrm{umol} / \mathrm{I}$ was obtained after the 10 days period at the highest dose $(3 \mathrm{ml} / 100 \mathrm{~g}$ body weight). Some of the biochemical indices evaluated in this study are useful parameters to indicate impairment in functional capacities of the renal organs. Blood Urea Nitrogen is a waste product derived from protein breakdown in the liver. Elevated levels of plasma urea can be caused by excessive protein intake, certain drugs and low fluid intake and kidney damage. The clinical importance of the urea level in plasma is normally determined in conjugation with the plasma creatinine level [27]. Creatinine is measured primarily to assess kidney function and has certain advantages over the measurement of urea. The plasma levels of creatinine is relatively independent of protein ingestion, water intake, rate of urine production and exercise. Since its rate of production is constant, elevation of plasma creatinine is indicative of under excretion, suggesting kidney impairment. Very low levels of plasma creatinine are rare and not clinically significant [29].

\section{CONCLUSION}

The significant decrease in the values of plasma urea and creatinine levels, point to the fact that the entire renal functions are not compromised following the administration of the aqueous extract of Sphenostylis stenocarpa. The decrease on the urea and creatinine levels may be contributing to the reduction in high blood pressure in the individuals taking this tea extract. Furthermore, the study showed that the aqueous extract had no harmful effects on the liver profile of the rats.

\section{COMPETING INTERESTS}

Authors have declared that no competing interests exist.

\section{REFERENCES}

1. Osuagwu AN, Nwofia GE. Effects of spent engine oil on the germination ability of eleven accessories of Africa yam bean seeds (Sphenostylis stenocarpa) Harms. J of Agric. and Vet. Sci. 2014;7(1):59-62.

2. Achinewhu SC, Akah GN. Chemical, functional and sensory properties of African yam bean (Sphenostylis stenocarpa) and cowpeas (Vignaunigui culata). Plant Food for Human Nutri. 2003; 11:71-81.

3. Alozie YE, Udofia US, Lawal O, Ani IF. Nutrient composition and sensory properties of cake made from wheat and African yam bean flour blends. J. of Food Tech. 2009;7:115-118.

4. Klu GYP, Amoatey HM, Bansa D, Kumaga FK. Cultivation and uses of African yam bean (Sphenostylis stenocarpa) in the Volta Region of Ghana. The J. of Food Tech. in Africa. 2001;6:74-77. 
5. Adewale BD, Dumet DJ. African Yam Bean: A crop with food security potentials for Africa. Africa Tech. Deve. Foru. 2009; 6(34):66-71.

6. Adewale BD, Kehinde $\mathrm{OB}$, Aremu CO, Popoola JO, Dumet DJ. Seed metrics for genetic and shape determinations in African yam bean [Fabaceae] (Sphenostylis stenocarpa) harms. African J of Plant Sci. 2010;4(4):107-115.

7. Nnam NM. Chemical and sensory evaluation of vegetable milks from African yam bean. Plant Foods for Human Nutri. 1997;51:265-275.

8. Adewale BD, Dumet DJ, Vroh-Bi I, Kehinde OB, Ojo DK, Adegbite AE, Franco $\mathrm{J}$. Morphological diversity analysis of African yam bean and prospects for utilization in germplasm conservation and breeding. Genetic Resources and Crop Evolution. 2012;59(5):927-936.

9. Ene-Obong HN, Obizoba IC. Protein quality of some Nigerian traditional diets based on the African yam bean (Sphenostylis stenocarpa) and Pigeon pea (Cajanus cajan). Plant Foods for Human Nutrition. 1995;48:297-309.

10. Obizoba IC, Atti JV. Evaluation of the effect processing techniques on the nutrient and antinutrient contents of pearl millet (Penninsetum glaucam) seeds. Plants Foods for Human Nutri. 1994;45: 23-34.

11. Nnam NM. Nitrogen and mineral utilization of young children fed blends of fermented or unfermented corn (Zea mays) African yam bean (Sphenostylis stenocarpa) and cowpea (Vignaungui culata). Ecology of Food and Nutri. 1999;38:21-34.

12. Eromosele CO, Arogundade LA, Eromosele IC, Ademuyiwa O. Extractability of African yam bean (Sphenostylis sternocarpa) protein in acid, salt and alkaline aqueous media. Food Hydrocol. 2008;22:1622-1628.

13. Obiakor PN. Effect of fermentation on the nutrient and antinutrient composition of african yam bean seeds and pearl millet grains. Annual conference and scientific meeting. Nutri Society of Nig. 2008;30:6070.

14. Ifeyironwa FS, Eyzaquirre PB, Matig OE, Johns T. Managing biodiversity for food and nutrition security in West Africa; Building on indigenous knowledge for more sustainable livelihoods. Diet related chronic diseases and the double burden of malnutrition in West Africa. Standing Committee on Nutrition. 2006;33:22-29.

15. Porter D. Economic botany of Sphenostylis (Leguminosae). Econ. Bot. 1992;46(3): 262-275.

16. Amoatey HM, Klu GYP, Bansa D, Kumaga FK, Anoagye LM, Bentt-Lartey SO, Gamedoagbao DK. The African yam bean (Sphenostylis stenocarpa): A neglected crop in Ghana. West African Journal of Applied Ecology. 2000;1:53-60.

17. Uguru MI, Madukaife SO. Studies on the variability in agronomic and nutritive characteristics of African yam bean (Sphenostylis stenocarpa). Plant Production and Research J. 2001;6:10-19.

18. Edem DO, Amugo CT, Eka OU. Chemical composition of Yam Bean (Sphenostylis sternocarpa) Trop. Sci. 1990;30:59-63.

19. Kine BB, Eka OU, Aremu CY, Ifon ET Chemical evaluation of the nutritive value of African yam bean (Sphenostylis stenocarpa). Trop. J. Appl. Sci.1991;1:99102.

20. Standing Committee on Nutrition (SCN). Diet related chronic diseases and the double burden of malnutrion in West Africa. SCN news (Development in International Nutrition). 2006;33.

21. Nnam NM. Evaluation of the nutrient and sensory properties of porridges from African yam bean (Sphenostylis stenocarpa) and maize (Zea maysL.) flours. Nigeria Research in Edu. 2003;9: 49-54.

22. Fasoyiro SB, Ajibade SR, Onole AJ, Adeniyan ON, Farinde EO. Proximate, minerals and anti nutritional factors of some under-utilized grain legumes in South-Western Nigeria. Nutritional and Food Sci. 2006;36:18-23.

23. Ene-Obong HN, Carnovale EA. Comparison of the proximate and mineral and amino acid composition of some lesser known legumes in Nigeria. J. of Food Chem. 1992;43:169-175.

24. Soetan KO. Pharmacological and other beneficial effects of anti-nutritional factors in plants: A review. African J. of Biotech. 2008;7(25):4713-471.

25. Nwokolo E. A nutritional Assessment of African yam bean Sphenostylis stenocarpa Harms and bambara groundnut, Voandzera subterranean L. Journal of the 
Science of Food and Agriculture. 1987;41: 123-129.

26. Wootton AM, Neale G, Moss DW. Enzyme activities ofcells of different types isolated from livers of normal and cholestatic rats. Clin Sci Mo. Med. 1977;52:585-590.

27. Okoye NF, Uwakwe AA, Ayalogu EO. A study of the effects of oral contraceptive on plasma urea of wistar albino rat Rattusrattus. Global J. of Pure and App. Sci. 2011;17(4):349-353.

28. Okoye NF, Nyimone PD. Effects of bentonite o plasma urea and creatinine of Wistar Albino Rats. Scientia African. 2015; 14(2):163-169.

29. Okoye NF, Uwakwe AA, Ayalogu EO. Effects of oral contraceptive - Microgynon and Primolut- $\mathrm{N}$ on plasma creatinine of wistar albino rat. Indian J. of Medicine and Healthca. 2012;1(7):2278-2966.

30. Wheatley VR. An improved diacetyl reaction for the estimation of urea in blood. Biochem J. 1948;43(3):420-422.
31. Henry RJ. Clinical Chemistry, Principles and techniques, $2^{\text {nd }}$ Edition. Harper and Row. 1974;525.

32. Tietz NW. Clinical Guide to laboratory tests. 2nd ed., Philadelphia, Pa: WB Saunders Co.1990;444-446.

33. Traymor J, Mactier R, Geddes CC, Fox $J G$. How to measure renal function in clinical practice. Bri. Med. J. 2006;333 (7571):733-737.

34. Mayne PD. Plasma enzymes in diagnosis. Clinical chemistry in diagnosis and treatment. London: Edward Arnold Publications 6th ed. 1998;147-150.

35. Adewale B, Daniel A, Aremu CO. The Nutritional Potentials and Possibilities in African yam bean for Africans. Inter. J. of Agric. 2013;3(1):8-19.

36. Anosike, CA, Obidoa A, Ezeanyika LUS. Beneficial effects of soybean diet on serum marker enzymes, lipid profile and relative organ weights of Wister rats. Pak. J. of Nutri. 2008;7(6):817-822.

(0) 2017 Franca and Monica; This is an Open Access article distributed under the terms of the Creative Commons Attribution License (http://creativecommons.org/licenses/by/4.0), which permits unrestricted use, distribution, and reproduction in any medium, provided the original work is properly cited.

Peer-review history:

The peer review history for this paper can be accessed here: http://sciencedomain.org/review-history/19940 